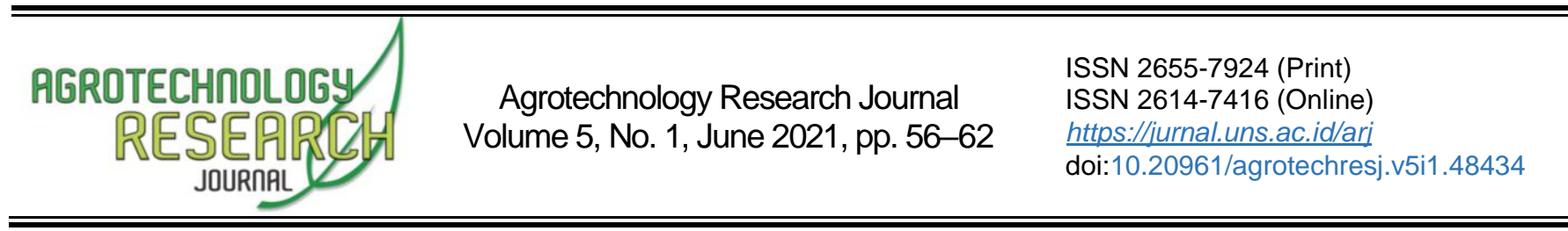

\title{
Karakteristik Sifat Kimia Tanah Lahan Gambut di Perkebunan Kencur Desa Sei Baru Kecamatan Panai Hilir Kabupaten Labuhanbatu
}

\section{Characteristics of Soil Chemical Properties of Peatlands in Galangal Plantation in Sei Baru Village, Panai Hilir District, Labuhanbatu Regency}

\author{
Asnan Siregar ${ }^{1}$, Hilwa Walida ${ }^{2 *}$, Kamsia Dorliana Sitanggang ${ }^{3}$, Fitra Syawal Harahap ${ }^{4}$, Yudi Triyanto 5 \\ ${ }^{1-5}$ Agrotechnology Study Program, Faculty of Science and Technology, Universitas Labuhanbatu, Labuhanbatu, Sumatera Utara, \\ 21418, Indonesia
}

Received 13 December 2020; Accepted 30 May 2021; Published 30 June 2021

\begin{abstract}
Farmers in Sei Baru village manage marginal peatlands for producing the galangal. So far, testing of soil characteristics has never been carried out. Fertilization and culture practices are just based on knowledge from generation to generation, so it is important to study the characteristics of soil chemical properties of the peatlands that have been used for producing galangal. The research was conducted from December 2020 until February 2021 in a galangal plantation-grown by the community in Sei Baru Village, Panai Hilir District, Labuhanbatu Regency. The method used was a free grid survey method at the semi-detailed survey level. The implementation of soil sampling of 5 sample points with a distance of 100 meters in the field using a random method spread over a predetermined area. The results showed that the peat soil planted with galangal in Sei Baru Village had a pH of around 4.542, Corg was $52.18 \%$, organic matter was $89.972 \%$, $\mathrm{N}$-total was $1.418 \%$, $\mathrm{C} / \mathrm{N}$ was 36.852 , P-Bray was $963.41 \mathrm{ppm}$, and K-total was 0.14. Overall, the chemical properties of the soil in galangal plantations Sei Baru Village, Panai Hilir District, Labuhanbatu Regency are in good condition.to increase its fertility for galangal cultivation, it can be done by increasing the $\mathrm{pH}$ and potassium in the soil so that it will become more favorable for growing galangal and can be used as a recommendation for galangal fertilization.
\end{abstract}

Keywords: Free Grid Survey; Kaempferia galanga; Organic Matter; Soil Sampling

Cite this as (CSE Style): Siregar A, Walida HM, Sitanggang KD, Harahap FS, Triyanto Y. 2021. Karakteristik sifat kimia tanah lahan gambut di perkebunan kencur Desa Sei Baru Kecamatan Panai Hilir Kabupaten Labuhanbatu. Agrotechnology Res J. 5(1): 56-62. https://dx.doi.org/10.20961/agrotechresj.v5i1.48434.

\section{PENDAHULUAN}

Indonesia memiliki luas lahan gambut sekitar 22,5 juta hektar dan termasuk 5 besar negara pemilik lahan gambut di dunia. Provinsi Sumatera Utara merupakan salah satu dari 10 provinsi dengan gambut terluas di Indonesia yaitu sebesar 0,6 juta hektar (CIFOR 2019). Lahan gambut menjadi kawasan yang tidak berguna dan bernilai rendah karena spesifikasi geologi dan lingkungan: dasar tanah yang lemah dan tidak stabil, kadar air yang tinggi, vegetasi yang jarang, kondisi lingkungan yang tidak sesuai untuk pertanian. Namun, jumlah lahan gambut yang tinggi berpotensi untuk dilakukan pengelolaan dan pengembangkan untuk pertanian. Pengelolaan lahan gambut Indonesia terhambat oleh peta distribusi yang kurang dan

${ }^{*}$ Corresponding Author:

E-Mail: hw2191@gmail.com karakteristik sifat dan kimia tanah gambut (Vincevicagaile et al. 2021).

Lahan gambut memiliki potensi untuk budidaya tanaman pangan (Choo et al. 2020). Berdasarkan hasil penelitian Putra et al. (2021) bahan amandemen dapat meningkatkan kandungan bahan organik tanah dan hasil produksi padi di lahan gambut. Hal ini menunjukkan bahwa pengembangan lahan gambut tidak hanya bergantung pada sifat fisik dan kimia, tetapi juga dipengaruhi oleh pengelolaan (Günther et al. 2020). Lahan gambut terbentuk dari tumpukan sisa tanaman yang terjebak dan terhambat proses dekomposisi akibat kejenuhan air (anaerobik) (Gabov et al. 2020). Pemanfaatan lahan gambut saat ini belum optimal karena tingkat kesuburan rendah yaitu tingkat kemasaman tinggi yang bersifat toksik bagi tanaman (Khotimah et al. 2020). Lahan gambut di Indonesia sangat dipengaruhi oleh suhu dan kelembaban tinggi yang dikombinasikan dengan curah hujan yang tinggi dan erosi tanah. Oleh karena itu, diperlukan pendekatan stabilisasi tanah yang berkelanjutan, salah satunya dengan pemanfaatan kencur. Kencur dapat digunakan 
sebagai bioremediasi pada lahan sub optimal. Berdasarkan hasil penelitian Basak (2019) bahwa kencur dapat meningkatkan kualitas tanah salin dengan menukar $\mathrm{Na}^{+}$dengan melarutkan $\mathrm{Ca}^{2+}$ secara efektif dalam larutan tanah dan mempertahankan hasil biologis.

Kencur (Kaempferia galanga L.) tergolong ke dalam famili Zingiberaceae yang kini telah dikembangkan di Pulau Jawa dan di luar Jawa seperti Sumatera Barat, Sumatera Utara, dan Kalimantan Selatan (Widyantika dan Prijono 2019). Desa Sei Baru merupakan salah satu desa yang ada di Kecamatan Panai Hilir, Kabupaten Labuhanbatu, Sumatera Utara, Indonesia. Petani di Desa Baru Sei menggunakan berbagai metode pengelolaan untuk menanam kencur dengan mengelola lahan gambut marginal sebagai lahan produktif. Namun sifat tanah tersebut belum pernah diuji, sehingga pemupukan dan pemeliharaan dilakukan berdasarkan pengetahuan turun-temurun. Oleh karena itu, penting untuk mempelajari karakteristik tanah gambut yang telah ditanami kencur. Selain sebagai tanaman obat, kencur dapat mengurangi erosi (Silalahi et al. 2015).

Pertumbuhan optimal kencur membutuhkan lahan dengan agroklimat yang sesuai (Mahanta et al. 2020). Agroklimat terbaik untuk budidaya kencur adalah Iklim tipe $A$, tipe $B$, dan tipe $C$ (Schmidt-Ferguson), dengan ketinggian 50-600 meter di atas permukaan laut, dan suhu tahunan rata-rata $25-30^{\circ} \mathrm{C}$. Curah hujan tahunan untuk pertumbuhan kencur berkisar antara 2.500 dan $4.000 \mathrm{~mm}$ dengan intensitas cahaya penuh (100\%), atau tanaman ternaungi (25-30\%) sampai umur 6 bulan, tanah berdrainase baik, memiliki tekstur tanah lempung sampai lempung liat berpasir dengan kemiringan lereng $<3 \%$, jenis tanah latosol, regosol, latosol-androsol berasosiasi, regosol-latusol, dan regosol-litosol, $\mathrm{pH}$ tanah 5,5-6,5 (Subaryanti et al. 2021).

Kemajuan industri farmasi konvensional dan usaha lain yang memanfaatkan kencur sebagai bahan baku menyebabkan permintaan kencur cenderung meningkat di tahun-tahun berikutnya, yang memerlukan upaya pengembangan yang dapat menjamin ketersediaan kencur secara berkelanjutan. Salah satu upaya untuk meningkatkan produktivitas kencur adalah dengan menggunakan lahan marginal. Lahan marginal memiliki prospek yang besar untuk pengembangan pertanian untuk pembangunan pertanian, namun diperlukan teknologi inovatif untuk meningkatkan produktivitas lahan marginal (Yuwono, 2009). Menurut DPMPPTSP (2020) Kecamatan Panai Hilir adalah salah satu kecamatan di kabupaten Labuhanbatu yang merupakan penghasil kencur terbesar di Indonesia yaitu dengan luas tanaman 700 hektar dan jumlah produksi sebesar 21.000 ton.tahun $^{-1}$. Teknik budidaya yang tepat sangat tergantung pada bahan tanam, iklim dan kondisi tanah termasuk karakteristik sifat kimia tanah. Oleh karena itu penting untuk dilakukan penelitian pengamatan karakteristik sifat kimia tanah untuk mengetahui kesesuaian syarat tumbuh kencur di suatu lokasi dan memberikan rekomendasi pemupukan kencur. Penelitian ini bertujuan untuk mengidentifikasi karakteristik sifat kimia tanah gambut di perkebunan Kencur di Desa Sei Baru Kecamatan Panai Hilir Kabupaten Labuhanbatu.

\section{BAHAN DAN METODE}

Penelitian dilaksanakan pada perkebunan tanaman kencur di Desa Sei Baru Kecamatan Panai Hilir Kabupaten Labuhanbatu (Gambar 1) dengan ketinggian tempat 4 meter diatas permukaan laut dari bulan Desember 2020 sampai bulan Februari 2021. Analisis sifat kimia tanah dilakukan di Laboratorium Analitik PT. Socfin Indonesia (Socfindo) Kebun Bangun Bandar. Analisis sifat kimia tanah gambut yaitu: $\mathrm{pH}$ tanah, C-organik metode Walkley dan Black (\%), bahan organik metode C-organik x 1,724, $\mathrm{N}$ - total (\%) dengan metode Kjeldahl, $\mathrm{C} / \mathrm{N}$ dengan metode pembagi kandungan $\mathrm{C}$-organik dan $\mathrm{N}$-total, $\mathrm{P}$-tersedia dengan metode Bray II, K-total dengan metode $\mathrm{NH}_{4} \mathrm{OAc} \mathrm{pH} 7$.

Bahan yang digunakan dalam penelitian ini adalah sampel tanah gambut yang ditanami tanaman kencur di Desa Sei Baru. Alat yang digunakan adalah bor tanah, Global Positioning System (GPS) dan pH meter. Jumlah sampel untuk analisis kimia tanah sebanyak 5 sampel. Metode yang digunakan dalam penelitian ini adalah metode survei grid bebas tingkat survei semi detail (kerapatan pengamatan 1 sampel tiap 100 meter). Pelaksanaan pengambilan contoh tanah sebanyak 5 titik sampel dengan jarak 100 meter di lapangan yang menggunakan metode acak tersebar dengan luasan yang telah ditentukan dengan berpedoman pada peta dasar (Rauf dan Harahap 2019). Pengambilan sampel tanah dilakukan secara zig-zag pada kedalaman 0-20 $\mathrm{cm}$. Dilakukan pembacaan koordinat pada GPS dan pengukuran kedalaman efektif tanah dengan ke dalam 4-5 mdpl.

\section{HASIL DAN PEMBAHASAN}

Berdasarkan hasil penelitian ini bahwa tanah gambut di Desa Sei Baru terletak di pantai di Kecamatan Panai Hilir Kabupaten Labuhanbatu merupakan tanah gambut yang terkena pasang surut air laut sehingga tanah tergolong subur dan produktif. Hal tersebut menyebabkan petani dapat bercocok tanam di wilayah tersebut dengan baik. Salah satu komoditas yang dibudidayakan yaitu kencur. Tanah gambut Indonesia umumnya memiliki tingkat kesuburan oligotrofik yang tebal dan miskin unsur hara, sedangkan gambut pantai termasuk ke dalam gambut eutrofik yang disebabkan oleh air pasang yang tinggi sehingga gambut pesisir tergolong gambut kaya nutrisi (Qadafi et al. 2021).

\section{pH tanah}

Hasil penelitian menunjukkan bahwa tanah gambut bekas tanaman kencur di Desa Sei Baru memiliki $\mathrm{pH}$ masam pada titik pengamatan $A, C$ dan $E$ (Tabel 1). Data $\mathrm{pH}$ tanah hasil penelitian dibandingkan dengan kriteria Balittanah (2009). Tanah gambut pada titik sampel B dan D adalah sangat masam yaitu 4,54. Salah satu karakteristik tanah gambut adalah $\mathrm{pH}$ tanah yang rendah. Tingkat kemasaman yang tinggi disebabkan oleh kondisi drainase dan hidrolisis asam-asam organik (Qadafi et al. 2021). Lahan gambut umumnya mempunyai tingkat kemasaman yang relatif tinggi dengan kisaran pH 3-5 (Zhang et al. 2021). pH tanah $(4,23-4,89)$ pada lokasi ini belum sesuai dengan syarat tumbuh kencur. Pertumbuhan optimal kencur membutuhkan pH tanah 5,5-6,5 (Kumar 2020). 


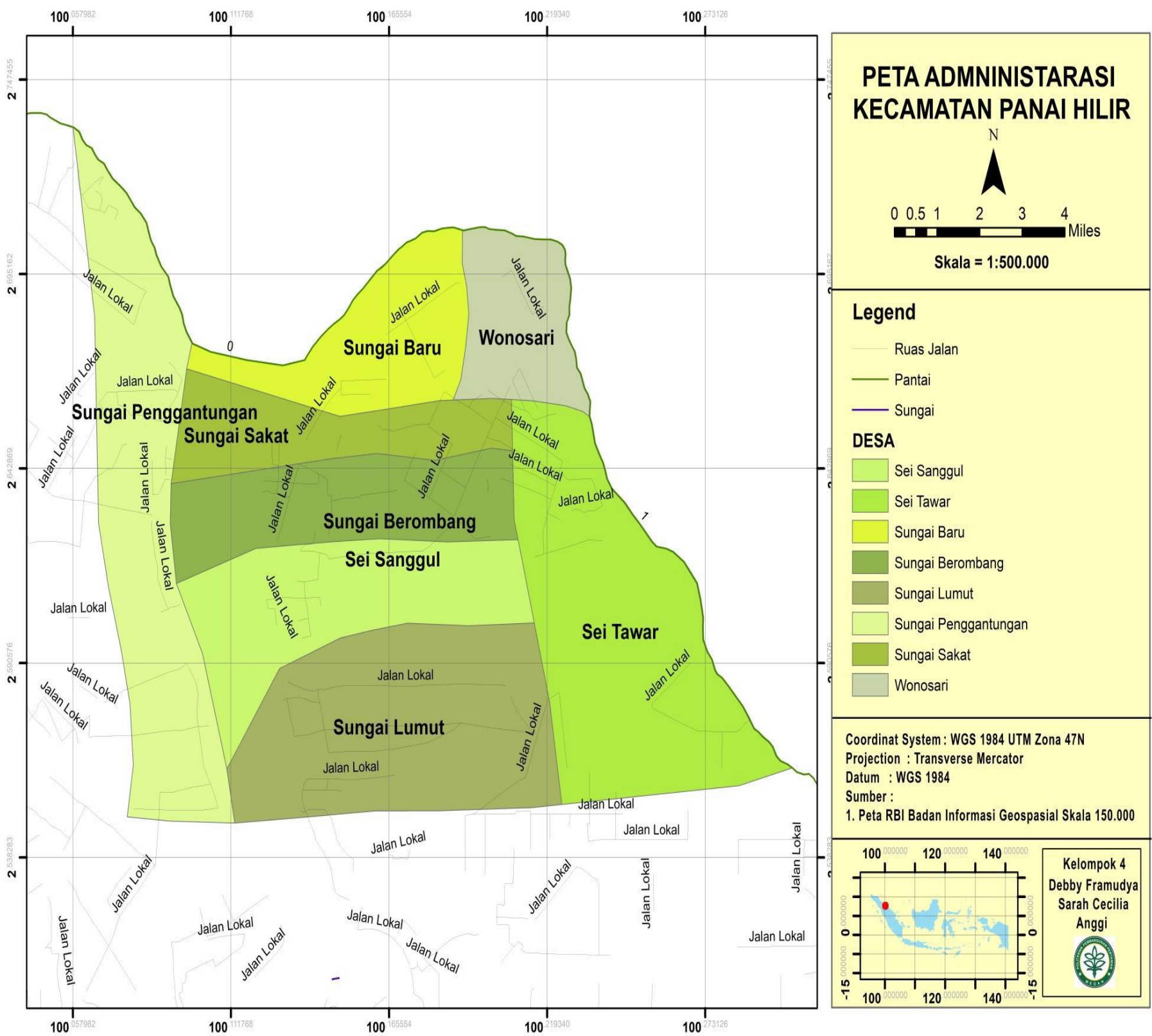

Gambar 1. Peta lokasi penelitian

Tabel 1. Data hasil analisis sifat kimia tanah gambut yang ditanami kencur

\begin{tabular}{|c|c|c|c|c|c|c|c|}
\hline \multirow[b]{2}{*}{ Sampel } & \multicolumn{7}{|c|}{ Parameter } \\
\hline & $\mathrm{pH}$ & $\begin{array}{c}\text { C-organik } \\
(\%)\end{array}$ & $\begin{array}{c}\text { Bahan Organik } \\
(\%)\end{array}$ & $\begin{array}{c}\text { N-Total } \\
(\%)\end{array}$ & $\mathrm{C} / \mathrm{N}$ & $\begin{array}{l}\text { P-Brayll } \\
\text { (ppm) }\end{array}$ & K-Total \\
\hline A & 4,73 & 52,64 & 90,75 & 1,48 & 35,57 & 972,39 & 0,15 \\
\hline B & 4,23 & 51,86 & 89,41 & 1,32 & 39,29 & 923,29 & 0,13 \\
\hline C & 4,89 & 52,35 & 90,25 & 1,43 & 36,61 & 976,59 & 0,19 \\
\hline D & 4,32 & 52,22 & 90,03 & 1,42 & 36,77 & 997,39 & 0,11 \\
\hline $\mathrm{E}$ & 4,54 & 51,87 & 89,42 & 1,44 & 36,02 & 947,39 & 0,12 \\
\hline Rataan & 4,542 & 52,18 & 89,972 & 1,418 & 36,852 & 963,41 & 0,14 \\
\hline
\end{tabular}

Upaya yang dapat dilakukan untuk meningkatkan $\mathrm{pH}$ tanah yang terlalu masam $(4,5-5,0)$ dengan kapur pertanian (kaptan/dolomit) sebanyak 1-2 tha ${ }^{-1}$ untuk meningkatkan pH sampai 5,5 - 6,5 (Yang et al. 2021). Tanah gambut pada penelitian ini memiliki $\mathrm{pH}$ yang lebih tinggi jika dibandingkan dengan hasil penelitian Hikmatullah dan Sukarman (2014) yaitu pH tanah pada tanah gambut di empat lokasi percobaan adalah berkisar antara 3,3 hingga 3,9 di semua lapisan tanah, kecuali di Situs-2 sedikit lebih tinggi ( $\mathrm{pH} 4.0$ hingga 4.2). $\mathrm{pH}$ merupakan faktor penting yang membatasi penguraian bahan organik (Masud et al. 2020). Tingkat kemasaman tanah pada penelitian ini berkorelasi dengan tingkat kejenuhan Al. pH mempengaruhi ketersediaan hara 
serta kelarutan Al dan Fe dalam tanah yaitu $\mathrm{pH}$ asam menyebabkan kelarutan $\mathrm{Al}$ dan Fe meningkat. $\mathrm{pH}$ tanah yang berubah secara signifikan dan tergolong asam kuat menyebabkan mikroorganisme sulit menguraikan bahan organik. $\mathrm{pH}$ merupakan faktor pembatas dekomposisi bahan organik karena mempengaruhi aktivitas mikroorganisme tanah (Zhou et al. 2021).

\section{C-organik (\%)}

Berdasarkan hasil penelitian bahwa tanah gambut yang ditanami kencur di Desa Sei Baru memiliki kandungan C-organik sebesar 52,18\% dan termasuk kriteria sangat tinggi (Balittanah 2009). Hal ini disebabkan karena tingkat kedalaman gambut, kematangan dan kadar abu yang semakin tinggi, maka kandungan karbon akan semakin tinggi (Wang et al. 2013). Kandungan bahan organik tanah gambut dapat berkisar antara 30 sampai mendekati 100\% (Noor et al, 2014). Kandungan C-organik pada tanah gambut (histosol) minimal 12\% dan pada gambut fibrik C-organik mencapai 60\% (Tonks et al. 2017).

Tanah gambut menyimpan karbon lebih besar daripada tanah mineral. Tiga jalur mendasar untuk penataan lahan gambut adalah terestrialisasi, paludifikasi dan penataan gambut esensial. Terestrialisasi mengacu pada pengisian kerangka limnik dengan lumpur alami. Lapisan yang umum dapat berupa lapisan dasar Gyttja, di bawah lapisan gambut yang lebih muda (Corradini et al. 2020). Paludifikasi mengacu pada kenaikan permukaan air yang memulai penataan gambut di tanah sebelumnya yang kurang lembap. Penataan gambut esensial mengacu pada pembentukan gambut khususnya pada lapisan lempung mineral lembap (Valois et al. 2020). Perbedaan penataan ini mengakibatkan perbedaan klasifikasi tanah gambut. Klasifikasi lahan gambut umumnya telah dikolaborasi dengan fokus tertentu, sehingga sangat berbeda apabila dikaitkan dengan tujuan seperti dukungan untuk pengambilan keputusan tentang penggunaan lanskap, perlindungan keanekaragaman hayati dan sistem klasifikasi tanah (Medina-alonso et al. 2020).

\section{Bahan organik (\%)}

Berdasarkan hasil penelitian bahwa tanah gambut yang ditanami kencur di Desa Sei Baru memiliki kandungan bahan organik sebesar 89,9725 (Tabel 1). Kandungan bahan organik yang tinggi tersebut disebabkan karena terbentuk oleh bahan organik dalam fisiologi cekungan atau rawa yang dipengaruhi oleh pasokan bahan organik ke tanah dari vegetasi yang tumbuh di atas tanah tersebut. Bahan organik tinggi dibentuk oleh akumulasi sisa tanaman setengah membusuk (Noor et al. 2014). Kandungan mineral gambut di Indonesia kurang dari 5\%, sisanya adalah bahan organik. Bagian organik terdiri dari sekitar $10 \%$ sampai $20 \%$ senyawa humus, dan sebagian besar lainnya adalah lignin, selulosa, hemiselulosa, lilin, tanin, resin, gabus, protein dan senyawa lainnya (Agus dan Subiksa 2008).

Gambut adalah jenis tanah yang terbentuk dari akumulasi sisa-sisa tumbuhan yang setengah membusuk; oleh sebab itu, kandungan bahan organiknya tinggi. Namun karena terbatasnya unsur hara yang terkandung, tanah gambut cenderung kurang subur. Lahan gambut merupakan pusat siklus hidrologi, melalui penyimpanan air, pengaturan kualitas air, pengisian air tanah, serta mitigasi banjir dan kekeringan. Gambut juga memainkan peran kunci dalam konservasi keanekaragaman hayati, arkeologi dan arsip paleoenvironmental (Chen et al. 2018).

\section{$\mathrm{N}$-total (\%)}

Berdasarkan hasil penelitian bahwa tanah gambut yang ditanami kencur di Desa Sei Baru memiliki kandungan $\mathrm{N}$ total sebesar $1,418 \%$. Tabel 1 menunjukkan bahwa hasil analisis $\mathrm{N}$-total (\%) tanah pada semua titik pengamatan termasuk kriteria sangat tinggi (Balittanah 2009). Kandungan $\mathrm{N}$ dalam tanah gambut sangat tinggi, sebagian besar $\mathrm{N}$ berada dalam bentuk organik (Noor et al. 2014). Bahan organik merupakan salah satu sumber $\mathrm{N}$ total dalam tanah, sehingga apabila kandungan bahan organik tinggi maka kandungan $\mathrm{N}$ dalam tanah juga meningkat Ketersediaan (Zhu et al. 2018). N juga memiliki keterkaitan dengan $\mathrm{C} / \mathrm{N}$ rasio. Berdasarkan Li et al. (2021) bahwa rasio $\mathrm{C} / \mathrm{N}$ yang berkisar antara 20 - 30 dapat menyebabkan imobilisasi mikrobiologi tanah dan pembebasan $\mathrm{N}$ ke dalam tanah gambut. $\mathrm{C} / \mathrm{N}$ rasio dengan kisaran 20-30 menyebabkan kandungan $\mathrm{N}$ tinggi.

Hara nitrogen pada tanah gambut pada penelitian ini termasuk sangat tinggi. Kandungan nitrogen yang tinggi dapat bermanfaat untuk merangsang pertumbuhan vegetatif tanaman (pertumbuhan akar, batang dan daun), pembentukan zat hijau daun (klorofil) untuk melakukan proses fotosintesis (Guinet et al. 2020). Hal ini dapat menjadi gambaran rekomendasi pemupukan kencur. Dosis pemupukan nitrogen per ha untuk kencur adalah 200-250 kg Urea atau bergantung kepada kesuburan tanah. Urea diberikan 3 kali, yaitu pada saat tanaman berumur 1, 2 dan 3 bulan setelah tumbuh dengan dosis 1/3 (Srivastava et al. 2020).

\section{C/N tanah}

Tabel 1 menunjukkan bahwa $\mathrm{C} / \mathrm{N}$ tanah di titik pengamatan termasuk pada kriteria sangat tinggi (Balittanah 2012). Hasil analisis menunjukkan $\mathrm{C} / \mathrm{N}$ rasio pada plot penelitian berkisar antara 35-36 pada lokasi tanaman kencur. Menurut Qadafi et al. (2021) yaitu rasio $\mathrm{C} / \mathrm{N}$ yang tinggi $(\mathrm{C} / \mathrm{N}>20)$ menunjukkan bahwa laju dekomposisi belum meningkat. Semakin tinggi rasio $\mathrm{C} / \mathrm{N}$, semakin rendah tingkat penguraian yang terjadi. Berdasarkan hasil tersebut bahwa lapisan gambut yang berada di atas permukaan air tanah memiliki tingkat dekomposisi yang lebih tinggi dibandingkan dengan lapisan gambut di bawah permukaan air tanah.

Rasio C/N tanah organik yang terbentuk oleh akumulasi gambut memiliki rasio yang lebih tinggi daripada tanah mineral. Rasio $\mathrm{C} / \mathrm{N}$ pada lahan gambut di belahan bumi utara rata-rata 49,0 (Zhang et al. 2021); sedangkan rata-rata rasio $\mathrm{C} / \mathrm{N}$ pada tanah mineral hanya 10,98 . Hal ini menunjukkan jejak mikroba yang kurang menonjol pada stoikiometri bahan organik tanah gambut dibandingkan dengan bahan organik tanah mineral, berbanding lurus dengan penampilan visual tanah yang sering berserat atau hemik (Hoyos-Santillan et al. 2016).

Keterkaitan yang erat antara kandungan organik tanah dan nutrisi organik akan menyebabkan penyerapan kandungan organik tanah dan nutrisi di 
tanah mineral (Kirkby et al. 2013) dan, sebaliknya, mendorong pelepasan $\mathrm{N}$ bersih dari tanah mineral yang berbanding terbalik dengan tanah. Rasio C/N (Springob dan Kirchmann 2003). C/N yang tinggi menunjukkan ketersediaan nutrisi tanaman yang rendah dan rotasi yang rendah. Keseimbangan lahan gambut perlu dijaga untuk menghindari kolonisasi spesies invasive (Garcíaleoz et al. 2018).

\section{P-Bray II}

Tabel 1 menunjukkan bahwa hasil analisis P-Bary II (ppm) tanah pada semua titik pengamatan termasuk kriteria sangat tinggi dengan rata-rata 963,41. Unsur hara fosfor $(P)$ pada tanah gambut berupa bahan $P$ organik. Kadar pelarutan fosfat di dalam tanah sangat lambat dibandingkan dengan ester lainnya, sehingga senyawa ini banyak terakumulasi, dan kandungannya di dalam tanah menyumbang lebih dari separuh fosfor organik atau seperempat dari total fosfor tanah (Servais et al. 2018). Ketersediaan fosfor sangat dipengaruhi oleh pH (Gao et al. 2019). Ion Al dan Fe yang larut dalam tanah menyebabkan $\mathrm{pH}$ rendah, sehingga dapat mengikat $P$ di dalam tanah. Hal tersebut menyebabkan kandungan fosfat pada tanah gambut tergolong tinggi.

Hasil penelitian ini menunjukkan bahwa fosfor tergolong sangat tinggi. Hal ini dapat menjadi gambaran rekomendasi pemupukan kencur. Berdasarkan Rahardjo dan Rostiana (2005) bahwa dosis pemupukan per ha yang diberikan pada kencur adalah 250 - $300 \mathrm{~kg}$ SP-36 atau bergantung kepada kesuburan tanah. SP-36 diberikan satu kali pada saat tanam atau ditunda sebulan apabila curah hujan belum cukup. Transformasi fosfor di lahan gambut bergantung pada tipe gambut, topografi dan manajemen budidaya. Proporsi relatif fraksi Po dan $P$ stabil lebih rendah di lahan gambut yang dikeringkan daripada di lahan gambut yang dibasahi (Li et al. 2021). Hasil penelitian menunjukkan bahwa pembasahan ulang jangka panjang tidak hanya mengunci $P$ dalam bahan organik tetapi juga mengubah $P$ labil menjadi fraksi $P$ stabil di cakrawala permukaan dari berbagai jenis lahan gambut.

\section{K-total}

Berdasarkan hasil penelitian bahwa rata-rata kandungan K-total adalah 0,14 (Tabel 1) dan termasuk kriteria rendah disesuaikan dengan kriteria Balittanah (2009). Hal ini sejalan dengan survei oleh Song et al. (2020) yaitu kandungan kalium ada tanah gambut rendah disebabkan oleh keasaman dan KTK yang lebih tinggi. Kandungan kalium yang rendah dapat disebabkan karena pengambilan unsur kalium oleh tanaman, pencucian kalium oleh air, dan erosi (McCarter et al. 2018). Kalium merupakan zat hara tumbuhan setelah nitrogen dan fosfor yang dibutuhkan tumbuhan dalam jumlah banyak dan berperan penting dalam proses fotosintesis (Wang dan Wu 2017).

Lahan gambut pada penelitian ini memiliki kandungan $\mathrm{K}$ yang rendah. Hal ini dapat menjadi gambaran rekomendasi pemupukan kalium kencur. Berdasarkan Rahardjo dan Rostiana (2005) bahwa dosis pemupukan per ha yang diberikan pada kencur adalah 250-300 kg KCl atau bergantung kepada kesuburan tanah. $\mathrm{KCl}$ diberikan satu kali pada saat tanam atau ditunda sebulan apabila curah hujan belum cukup. Kalium berfungsi antara lain untuk meningkatkan proses fotosintesis, mengefisienkan penggunaan air, mempertahankan turgor, membentuk batang yang lebih kuat, sebagai aktivator bermacam sistem enzim, dan meningkatkan ketahanan tanaman terhadap penyakit (Hasanuzzaman et al. 2018).

\section{KESIMPULAN}

Tanah gambut yang ditanami kencur di Desa Sei Baru memiliki sifat kimia sebagai berikut: $\mathrm{pH}$ sekitar 4,542 (masam), C-org sebesar 52,18\% (sangat tinggi), bahan organik sebesar $89,972 \%$ (sangat tinggi), $\mathrm{N}$-total sebesar 1,418\% (sangat tinggi), $\mathrm{C} / \mathrm{N}$ sebesar 36,852 (sangat tinggi), P-Bray sebesar 963,41 ppm (sangat tinggi), dan K-total sebesar 0,14 (rendah). Untuk meningkatkan kesuburan dalam budidaya kencur di Desa Sei Baru dapat dilakukan dengan meningkatkan $\mathrm{pH}$, dan kalium pada tanah agar sesuai syarat tumbuh kencur serta dapat dijadikan rekomendasi pemupukan kencur.

\section{DAFTAR PUSTAKA}

Agus F, Subiksa I. 2008. Lahan gambut: potensi untuk pertanian dan aspek lingkungan. Bogor (ID): Balai Penelitian Tanah dan World Agroforestry Centre (ICRAF).

[Balittanah] Balai Penelitian Tanah. 2009. Petunjuk teknis analisis kimia tanah, tanaman, air dan pupuk. Edisi 2. Bogor (ID): Balai Penelitian Tanah, Balai Besar Litbang Sumber Daya Lahan Pertanian, Badan Penelitian dan Pengembangan Pertanian, Departemen Pertanian. 204 p.

Basak BB. 2019. Phosphorus release by low molecular weight organic acids from low-grade Indian rock phosphate. Waste Biomass Valorization. 10:32253233. https://doi.org/10.1007/s12649-018-0361-3.

Chen S, Hong $\mathrm{H}$, Huang $\mathrm{X}$, Fang $\mathrm{Q}$, Yin $\mathrm{K}$, Wang $\mathrm{C}$, Zhang Y, Cheng L, Algeo TJ. 2018. The role of organo-clay associations in limiting organic matter decay: Insights from the Dajiuhu peat soil, central China. Geoderma. 320:149-160. https://dx.doi.org/10.1016/j.geoderma.2018.01.013.

Choo LNLK, Ahmed OH, Talib SAA, Ghani MZA, Sekot S. 2020. Clinoptilolite zeolite on tropical peat soils nutrient, growth, fruit quality, and yield of Carica papaya L. CV. Sekaki. Agronomy. 10(9):1320. https://dx.doi.org/10.3390/agronomy10091320.

[CIFOR] Center for International Forestry Research. 2019. CIFOR Annual report 2019: forest in a time crisis. Bogor (ID): Center for International Forestry Research.

[DPMPPTSP] Dinas Penanaman Modal dan Pelayanan Terpadu Satu Pintu Kabupaten Labuhanbatu. (2020). Profil Investasi Pemerintah Kabupaten Labuhanbatu. Labuhanbatu (ID).

Corradini E, Dreibrodt S, Erkul E, Groß D, Lübke $H$, Panning $D$, Pickartz $N$, Thorwart $M$, Vött $A$, Willershäuser T, et al. 2020. Understanding wetlands stratigraphy: Geophysics and soil parameters for investigating ancient basin development at lake $\begin{array}{ll}\text { duvensee. } & \text { Geosci. 10(8):314. }\end{array}$ https://dx.doi.org/10.3390/geosciences10080314. 
Gabov D, Yakovleva E, Vasilevich R. 2020. Vertical distribution of PAHs during the evolution of permafrost peatlands of the European arctic zone. Appl Geochemistry. 123:104790. https://doi.org/10.1016/j.apgeochem.2020.104790.

Gao S, DeLuca TH, Cleveland CC. 2019. Biochar additions alter phosphorus and nitrogen availability in agricultural ecosystems: a meta-analysis. Sci Total Environ. 654:463-472. https://dx.doi.org/10.1016/j.scitotenv.2018.11.124.

García-leoz V, Villegas JC, Suescún D, Flórez CP, Merino-martín L, Betancur T, León JD. 2018. Land cover effects on water balance partitioning in the Colombian Andes: improved water availability in early stages of natural vegetation recovery. Reg Environ Chang. 52:1117-1129. https://doi.org/10.1007/s10113-017-1249-7.

Guinet M, Nicolardot B, Voisin AS. 2020. Nitrogen benefits of ten legume pre-crops for wheat assessed by field measurements and modelling. Eur J Agron. 120:126151. https://dx.doi.org/10.1016/j.eja.2020.126151.

Günther A, Barthelmes A, Huth V, Joosten H, Jurasinski G, Koebsch F, Couwenberg J. 2020. Prompt rewetting of drained peatlands reduces climate warming despite methane emissions. Nat Commun. 11:1644. https://dx.doi.org/10.1038/s41467-020-15499-z.

Hasanuzzaman M, Bhuyan MHMB, Nahar K, Hossain MS, Al Mahmud J, Hossen MS, Masud AAC, Moumita, Fujita M. 2018. Potassium: a vital regulator of plant responses and tolerance to abiotic stresses. Agronomy. 8(3):31. https://dx.doi.org/10.3390/agronomy8030031.

Hikmatullah, Sukarman. (2014). Physical and chemical properties of cultivated peat soils in four trial sites of ICCTF in Kalimantan and Sumatra, Indonesia. J Trop Soils. 19(3):131-141. http://dx.doi.org/10.5400/jts.2014.v19i3.131-141.

Hoyos-Santillan J, Lomax BH, Large D, Turner BL, Boom A, Lopez OR, Sjögersten S. 2016. Quality not quantity: organic matter composition controls of $\mathrm{CO}_{2}$ and $\mathrm{CH}_{4}$ fluxes in neotropical peat profiles. Soil Biol Biochem. 103:86-96. https://doi.org/10.1016/j.soilbio.2016.08.017.

Khotimah S, Suharjono, Ardyati T, Nurani Y. 2020. Isolation and identification of cellulolytic bacteria at fibric, hemic and sapric peat in Teluk Bakung Peatland, Kubu Raya district, Indonesia. Biodiversitas. 21(5):2103-2112. https://dx.doi.org/10.13057/biodiv/d210538.

Kirkby CA, Richardson AE, Wade LJ, Batten GD, Blanchard C, Kirkegaard JA. 2013. Carbon-nutrient stoichiometry to increase soil carbon sequestration. Soil Biol Biochem. 60:77-86. https://doi.org/10.1016/j.soilbio.2013.01.011.

Kumar A. 2020. Phytochemistry, pharmacological activities and uses of traditional medicinal plant Kaempferia galanga L. - an overview. J Ethnopharmacol. 253:112667. https://dx.doi.org/10.1016/j.jep.2020.112667.
Li L, Konkel J, Jin VL, Schaeffer SM. 2021. Conservation management improves agroecosystem function and resilience of soil nitrogen cycling in response to seasonal changes in climate. Sci Total Environ. 779:146457. https://dx.doi.org/10.1016/j.scitotenv.2021.146457.

Mahanta BP, Sarma N, Kemprai P, Begum T, Saikia L, Lal M, Haldar S. 2020. Hydrodistillation based multifaceted value addition to Kaempferia galanga L. leaves, an agricultural residue. Ind Crops Prod. 154:112642. https://dx.doi.org/10.1016/j.indcrop.2020.112642.

Masud MM, Baquy MA Al, Akhter S, Sen R, Barman A, Khatun MR. 2020. Liming effects of poultry litter derived biochar on soil acidity amelioration and maize growth. Ecotoxicol Environ Saf. 202:110865. https://dx.doi.org/10.1016/j.ecoenv.2020.110865.

McCarter CPR, Weber TKD, Price JS. 2018. Competitive transport processes of chloride, sodium, potassium, and ammonium in fen peat. $J$ Contam Hydrol. 217:17-31. https://dx.doi.org/10.1016/j.jconhyd.2018.08.004.

Medina-alonso MG, Navas JF, Cabezas JM, Weiland CM, Ríos-mesa D, Lorite IJ, León L, Rosa R. 2020. Differences on flowering phenology under Mediterranean and Subtropical environments for two representative olive cultivars. Environ Exp Bot. 180:104239. https://dx.doi.org/10.1016/j.envexpbot.2020.104239.

Noor M, Masganti, Agus F. 2014. Pembentukan dan karakteristik gambut tropika Indonesia. In: Agus F, Anda M, Jamil A, Masganti, editors. Lahan gambut Indonesia: pembentukan, karakteristik, dan potensi mendukung ketahanan pangan. Edisi revisi, cetakan II 2016. Bogor (ID): IAARD Press, Badan Penelitian dan Pengembangan Pertanian, Kementerian Pertanian. $346 \mathrm{p}$.

Putra SS, Holden J, Baird AJ. 2021. The effects of ditch dams on water-level dynamics in tropical peatlands. Hydrol Process. 35(5):e14174. https://dx.doi.org/10.1002/hyp.14174.

Qadafi M, Notodarmojo S, Zevi Y. 2021. Performance of microbubble ozonation on treated tropical peat water: Effects on THM4 and HAA5 precursor formation based on DOM hydrophobicity fractions. Chemosphere. 279:130642. https://doi.org/10.1016/j.chemosphere.2021.130642.

Rahardjo M, Rostiana O. 2005. Budidaya tanaman kunyit. Bogor(ID): Balai Penelitian Tanaman Obat dan Aromatika. Sirkuler No. 11.

Rauf A, Harahap FS. (2019). Optimalisasi lahan pertanian menggunakan agen biomassa. Medan (ID): USU Press Medan.

Servais S, Kominoski JS, Charles SP, Gaiser EE, Mazzei V, Troxler TG, Wilson BJ. 2018. Saltwater intrusion and soil carbon loss: testing effects of salinity and phosphorus loading on microbial functions in experimental freshwater wetlands. Geoderma. 337:1291-1300.

https://doi.org/10.1016/j.geoderma.2018.11.013. 
Silalahi M, Nisyawati, Walujo EB, Supriatna J, Mangunwardoyo W. 2015. The local knowledge of medicinal plants trader and diversity of medicinal plants in the Kabanjahe traditional market , North Sumatra, Indonesia. J Ethnopharmacol. 175:432443. https://dx.doi.org/10.1016/j.jep.2015.09.009.

Song Y, Liu C, Wang X, Ma X, Jiang L, Zhu J, Gao J, Song C. 2020. Microbial abundance as an indicator of soil carbon and nitrogen nutrient in permafrost peatlands. Ecol Indic. 115:106362. https://dx.doi.org/10.1016/j.ecolind.2020.106362.

Springob G, Kirchmann H. 2003. Bulk soil C to N ratio as a simple measure of net $\mathrm{N}$ mineralization from stabilized soil organic matter in sandy arable soils. Soil Biol Biochem 35(4):629-632. https://doi.org/10.1016/S0038-0717(03)00052-X.

Srivastava A, Brooks ES, Dobre M, Elliot WJ, Wu JQ, Flanagan DC, Gravelle JA, Link TE. 2020. Science of the total environment modeling forest management effects on water and sediment yield from nested, paired watersheds in the interior Pacific Northwest, USA using WEPP. Sci Total Environ. 701:134877. https://dx.doi.org/10.1016/j.scitotenv.2019.134877.

Subaryanti S, Sulistyaningsih YC, Iswantini D, Triadiati T. 2021. Essential oil components, metabolite profiles, and idioblast cell densities in galangal (Kaempferia galanga L.) at different agroecology. AGRIVITA J Agric Sci. 43(2):245-261. https://dx.doi.org/10.17503/agrivita.v43i2.2631.

Tonks AJ, Aplin P, Beriro DJ, Cooper H, Evers S, Vane $\mathrm{CH}$, Sjögersten S. 2017. Impacts of conversion of tropical peat swamp forest to oil palm plantation on peat organic chemistry, physical properties and carbon stocks. Geoderma. 289:36-45. https://dx.doi.org/10.1016/j.geoderma.2016.11.018.

Valois R, Schaffer N, Figueroa R, Maldonado A, Yáñez E, Hevia A, Carrizo GY, MacDonell S. 2020. Characterizing the water storage capacity and hydrological role of mountain peatlands in the arid andes of North-Central Chile. Water. 12(4):1071. https://dx.doi.org/10.3390/W12041071.

Vincevica-gaile Z, Teppand T, Kriipsalu M, Krievans M, Jani Y, Klavins M, Setyobudi RH, Grinfelde I, Rudovica V, Tamm T, et al. 2021. Towards sustainable soil stabilization in peatlands: secondary raw materials as an alternative. Sustainability. 13(12):6726. https://doi.org/10.3390/su13126726.
Wang Y, Liu X, Butterly C, Tang C, Xu J. 2013. pH change, carbon and nitrogen mineralization in paddy soils as affected by Chinese milk vetch addition and soil water regime. J Soils Sediments. 13:654-663. https://dx.doi.org/10.1007/s11368-012-0645-3.

Wang Y, Wu WH. 2017. Regulation of potassium transport and signaling in plants. Curr Opin Plant Biol. 39:123128. https://dx.doi.org/10.1016/j.pbi.2017.06.006.

Widyantika SD, Prijono S. 2019. Pengaruh biochar sekam padi dosis tinggi terhadap sifat fisisk tanah dan pertumbuhan tanaman jagung pada Typic Kanhapludult. Tanah Sumberd Lahan. 6(1):1145-1156. http://dx.doi.org/10.21776/ub.jtsl.2019.006.1.14.

Yang L, Ru Y, Xu S, Liu T, Tan L. 2021. Bioresource technology features correlated to improved enzymatic digestibility of corn stover subjected to alkaline hydrogen peroxide pretreatment. Bioresour Technol. 325:124688. https://dx.doi.org/10.1016/j.biortech.2021.124688.

Yuwono NW. 2009. Membangun kesuburan tanah di lahan marginal. J IImu Tanah Lingkung. 9(2):137-141.

Zhang L, Gałka M, Kumar A, Liu M, Knorr KH, Yu ZG. 2021. Plant succession and geochemical indices in immature peatlands in the Changbai Mountains, northeastern region of China: implications for climate change and peatland development. Sci Total Environ. 773. https://dx.doi.org/10.1016/j.scitotenv.2020.143776.

Zhou C, Li C, Siva S, Cui H, Lin L. 2021. Chemical composition, antibacterial activity and study of the interaction mechanisms of the main compounds present in the Alpinia galanga rhizomes essential oil. Ind Crops Prod. 165:113441. https://dx.doi.org/10.1016/j.indcrop.2021.113441.

Zhu Z, Ge T, Liu S, Hu Y, Ye R, Xiao M, Tong C, Kuzyakov Y, Wu J. 2018. Rice rhizodeposits affect organic matter priming in paddy soil: the role of $\mathrm{N}$ fertilization and plant growth for enzyme activities, $\mathrm{CO} 2$ and $\mathrm{CH} 4$ emissions. Soil Biol Biochem. 116:369-377. https://dx.doi.org/10.1016/j.soilbio.2017.11.001. 